\title{
Explaining intermittent exporting: Exit and conditional re-entry in export markets
}

\author{
Michele Bernini ${ }^{1}$, Jun $\mathrm{Du}^{2}$ and \\ James $\mathrm{H}$. Love ${ }^{3}$ \\ ${ }^{1}$ National Institute of Economic and Social \\ Research, London, UK; ${ }^{2}$ Enterprise Research \\ Centre and Aston Business School, Aston \\ University, Birmingham, UK; ${ }^{3}$ Enterprise Research \\ Centre and Warwick Business School, University of \\ Warwick, Coventry CV4 7AL, UK
}

\section{Correspondence:}

James H. Love, Enterprise Research Centre and Warwick Business School, University of Warwick, Coventry CV4 7AL, UK

e-mail: jim.love@wbs.ac.uk
Received: 11 May 2015

Revised: 8 June 2016

Accepted: 9 June 2016

Online publication date: 22 August 2016

\begin{abstract}
Intermittent exporting is something of a puzzle. In theory, exporting represents a major commitment, and is often the starting point for further internationalization. However, intermittent exporters exit and subsequently re-enter exporting, sometimes frequently. We develop a conceptual model to explain how firm characteristics and market conditions interact to affect the decision to exit and re-enter exporting, and model this process using an extensive dataset of French manufacturing firms from 1997 to 2007. As anticipated, smaller and less productive firms are more likely to exit exporting, and react more strongly to changes in both domestic and foreign markets than larger firms. Exit and re-entry are closely linked. Firms with a low exit probability also have a high likelihood of re-entry, and vice versa. However, the way in which firms react to market conditions at the time of exit matters greatly in determining the likelihood of re-entry: thus re-entry depends crucially on the strategic rationale for exit. Our analysis helps explain the opportunistic and intermittent exporting of (mainly) small firms, the demand conditions under which intermittent exporting is most likely to occur, and the firm attributes most likely to give rise to such behavior.
\end{abstract}

Journal of International Business Studies (2016) 47, 1058-1076. doi: 10.1057/s41267-016-0015-2

Keywords: intermittent exporting; export exit; export re-entry; re-internationalization

The original version of this article was revised due to a retrospective Open Access order.

\section{INTRODUCTION}

The literature on internationalization is dominated by two theoretical approaches: the process approach and the international entrepreneurship (or 'born global') approach (Johanson \& Vahlne, 1977, 2009; Knight \& Cavusgil, 2004; Jones \& Coviello, 2005). Despite their differences, both approaches implicitly see becoming international as an important step in a firm's development, and one which is effectively irreversible. The process literature typically revolves around understanding what determines and mediates the process in which firms learn and increase resource commitments, but rarely addresses the reverse situation where resources are decreased or withdrawn. This tendency is perhaps even more evident in the 'born global' literature, in which it is assumed that relatively young enterprises quickly (and by implication permanently) achieve relatively high levels of international activity. 
However, for many firms the evidence suggests that becoming international is by no means irreversible, especially as regards one crucial part of internationalization: exporting. There is evidence that for many firms - especially SMEs - exporting is often a rather opportunistic and sporadic activity, rather than a continuous process. Recent analysis suggests that firms often engage in relatively intermittent exporting for extended periods, and that sporadic exporting is commonplace among UK SMEs without either entry to or exit from export markets being a coherent strategy (Crick, 2003; Requena-Silvente, 2005; Love \& Ganotakis, 2013). Similar results have been found for Italian SMEs, with repeated, serial entry and exit to and from export markets being relatively commonplace, and firms taking time to build up the experience and internal assets necessary to make export market entry a clear strategic decision (Bonaccorsi, 1992). Research on other countries suggests this is not a specifically European phenomenon, with similar patterns of intermittent exporting reported for Colombia (Eaton, Eslava, Kugler, \& Tybout, 2008) and Chile (Blum, Claro, \& Horstmann, 2013). However, while the phenomenon has been observed, there is little systematic analysis of the causes of intermittent exporting, or of the precise conditions that make it more likely to occur.

One of the problems with both conceptual and empirical research in this area is simply definitional: there is a problem of categorizing intermittent exporters even where longitudinal data series are available. Ex ante categorizations of intermittent exporters on the basis of their revealed behavior are bound to be arbitrary: each continuous exporter within a particular time window may have been an intermittent exporter before or after the period of observation (Blum et al., 2013). By contrast, the analysis we perform does not rely on ex ante categorization and arbitrary definition. Intermittent exporting must, by its nature, involve international market entry, followed by exit and subsequent re-entry: to understand fully the phenomenon of intermittent or sporadic exporters, each of these actions has to be understood. We now know a great deal about the first of these, with many studies of the exporting decision and its determinants: ${ }^{1}$ however, we know much less about the process of exit from export markets, and even less about re-internationalization via exporting (Welch \& Welch, 2009). The conceptual and empirical analysis below concentrates on this process of exit and (conditional) re-entry, the characteristics that define intermittent exporters. By concentrating on the exit and re-entry process we therefore avoid arbitrary ex ante classifications of 'continuous' or 'intermittent' exporters.

In doing so, our study provides three contributions towards understanding the puzzle of intermittent exporting. First, we extend theory by developing a new conceptual model of exit and re-entry, building on both the resource-based view of the firm and the process model of internationalization (Johanson \& Vahlne, 1977, 2006), augmented with insights from the performance feedback literature (Lages, Jap, \& Griffith, 2008; Lin, 2014). The model highlights the important roles of firms' internal resources and the nature of external demand (both domestic and foreign) in determining exit and re-entry, and provides testable hypotheses of the conditions under which export exit and re-entry - and hence intermittent exporting - will take place.

We then test the model on a very extensive dataset of firm-level export entries and exits over the period 1997-2007. This leads to the second contribution, which is a better understanding of the conditional nature of re-entry. We show that how firms react to market conditions at the time of exit is important in determining the likelihood of re-entry: we thus demonstrate that re-entry depends crucially on the strategic rationale for exit. Specifically, we are able to identify theoretically, and confirm empirically, the (exit) demand conditions under which re-entry, and thus intermittent exporting, is most likely to occur, and the firm attributes most likely to lead to intermittent exporting.

We make a third contribution to both researchers and policymakers by shedding light on a phenomenon that has previously been observed but never satisfactorily explained. We show how and why smaller and less productive firms react most strongly to changes in (domestic and foreign) demand conditions in terms of export exit and re-entry, and so we are able to account for the opportunistic and intermittent nature of exporting among such firms.

\section{CONCEPTUAL FRAMEWORK AND HYPOTHESES}

No single theoretical model fully explains the phenomenon of intermittent exporters. We therefore develop our conceptual framework based on two major theoretical perspectives to explain how firm characteristics and market conditions affect firms' decision to exit and re-enter exporting. Augmenting these theories with insights from the 
performance feedback literature, we develop a model of firm export exit and (possible) re-entry conditional on exit - the defining characteristics of intermittent exporters.

The first theoretical pillar is the resource-based view (RBV). Recent international trade theory has highlighted the importance of producer heterogeneity in explaining the dynamics in international trade (e.g., Melitz, 2003). Scholars in these fields have investigated intensively why firms export and how they benefit from exporting. While the economics literature has tended to regard firm-level productivity to be the 'catch-all' determinant of heterogeneous export behavior, the IB literature in parallel has adopted a more complex and nuanced view, and explored these questions in the framework of the resource-based view and firm-specific advantages (Dunning, 1980). An underlying assumption about these frameworks is that firms vary in their resource bundles and productive capacity (Barney, Wright, \& Ketchen, 1991). Both literatures reach similar conclusions - we now understand that to start exporting, firms need to be sufficiently productive or competitive to cover the sunk cost associated with export entry, including the costs of collecting market information, modifying products to global preferences, logistics and distribution. This is supported by a large body of empirical work (as reviewed by Wagner, 2007; ISGEP, 2008; Martins \& Yang, 2015).

The second strand of theories we draw on is the gradual process of internationalization. This includes the original Uppsala internationalization process models and the further developments that highlight the interplay between learning, commitment building and business network development (Johanson \& Wiedersheim, 1975; Johanson \& Vahlne, 1977, 2006, 2009). Here, the gradual learning process of internationalization is featured in which firms first gain experience from the domestic market before moving to foreign markets, starting their foreign operations from 'less foreign' countries (in terms of psychic distance) before moving to more foreign countries, and starting foreign operations by using traditional exports before gradually moving to more intensive and demanding operation modes such as sales subsidiaries and direct investment. This is a process in which firms develop market knowledge, decide foreign market commitments, and identify and develop opportunities. ${ }^{2}$

Despite their usefulness in explaining exporting and internationalization, neither the RBV nor the process model satisfactorily explains the phenomenon of intermittent exporting. The RBV concentrates on the internal resources of the firm, while the process model stresses learning from previous international experience coupled with decisions on likely future prospects in foreign markets in deciding on future commitment levels. In their more recent re-conceptualization of the process model, Johanson and Vahlne (2009) stress that commitment may decline, or even cease, if performance and prospects are not sufficiently promising. However, this is considered in the context of commitment to a given market, and does not specifically explain why some firms repeatedly enter, withdraw from, and re-enter exporting activity as a whole. More specifically, neither theoretical approach fully explains the interplay between demand conditions in both the domestic and potential export markets and internal firm characteristics in the decision to exit or re-enter exporting, nor the conditions under which firms react more or less strongly to changes in demand patterns in deciding whether to exit or re-enter exporting. We develop a conceptual model which does this, drawing on elements of the resource-based perspective and the process model, but augmenting both with an understanding of firms' reaction to domestic and foreign demand changes through the process of performance feedback.

Performance feedback describes a situation in which the firm evaluates performance against an aspirational level which is set either in terms of previous performance achievement, or through comparisons with competitors. Previous research suggests that performance feedback does play a role in internationalization, and especially in irregular and intermittent forms of internationalization. For example, in a study of Swedish SMEs, Wennberger and Holmquist (2008) find that performance below defined aspiration levels tended to increase the firm's search for opportunities to internationalize; and in a study of over 500 export managers, Lages et al. (2008) demonstrate that exporting performance is inversely correlated with the extent of change in exporting marketing strategy in the next period, consistent with performance feedback. More specifically, Lin (2014) shows that where performance is below the aspiration level, firms tend to respond not only by adopting more rapid internationalization, but also a more irregular pace of international expansion in order to improve performance.

The interplay between firms' internal resources and perceived opportunities in domestic and international markets drives the process of export entry, 
exit and potential re-entry. A firm engaged in domestic operations has the opportunity to employ its internal productive resources and its knowledge of the external environment to commit resources in the decision to start exporting. The firm's experience as an exporter then helps to shape its view of the profitable opportunities available in both domestic and overseas markets, and it decides whether to remain as an exporter or to exit exporting. This is done by comparing actual performance arising from exporting to the level considered acceptable. We argue below that this decision is influenced by the interaction between a firm's internal resources and demand conditions at home and abroad. Having made the exit decision, depending on its internal capacity and on the reasons for exit, the firm then faces the decision to remain as a domestic producer or re-enter exporting. Crucially, the re-entry decision is shaped by experiences and performance prior to and during the exit phase, including the rationale for exit. The re-entry decision is therefore a conditional one. Firms which go through all three stages culminating in re-entry are intermittent exporters, the focus of this article.

The detailed hypotheses underlying this process are developed below. As demonstrated in the empirical analysis, this model exhibits several useful features. It explains why intermittent exporting is more likely to be carried out by smaller, less resource-intensive firms, shedding light on the opportunistic and intermittent nature of exporting among small firms observed but largely unexplained in earlier research (e.g., Crick, 2004; Love $\&$ Ganotakis, 2013). The model also demonstrates that demand conditions at the time of exit, and the firm's reaction to these, are central to the probability of export re-entry, an issue not previously considered in empirical research. More generally, our analysis highlights the role of the firm's strategic choice in exit and re-entry, especially regarding reaction to changes in home and overseas demand.

The initial export entry decision is well researched in the IB and economics literatures. In the sections below we concentrate on developing the conceptual arguments and hypotheses for the exit and conditional re-entry stages that define intermittent exporters.

\section{Export Exit: Firm Resources and External Market Conditions}

We hypothesis that export exit is shaped both by perceived market demand conditions and on the interaction between the firm's internal resources and demand at home and overseas.

\section{External Market Conditions}

Firms make exit decisions strategically, based at least partly on expected earnings in the export market due to the changes in its external market opportunities. There is growing evidence that the globalization of markets and industries has fundamentally changed the competitive conditions facing firms (Colantone, Coucke, \& Sleuwaegen, 2008). Not only has the global market place become more competitive, but there are also more market opportunities from which firms can take advantage. Therefore, demand conditions in domestic and foreign markets are likely to play a role in the exit decision alongside the firm's internal resources.

Export and domestic sales are closely linked. There is ample macro-level evidence that exports can be motivated both by improved global trade condition and by domestic crisis or depression (Greenaway \& Kneller, 2007). Indeed, Salomon and Shaver (2005) argue that export sales and domestic sales should be determined simultaneously: their relationship is interdependent rather than independent. In a similar vein, Belke, Oeking, and Setzer (2015) argue that under certain conditions, firms consider export activity as a substitute for serving domestic demand. One potential limitation of the previous literature is that the 'complementarity' versus 'substitutability' property of domestic demand and export activity has typically been analysed in a linear framework. The relationship between domestic demand and export performance may, however, vary with economic conditions and thus be of a nonlinear nature.

Some empirical evidence supports this view. Based on firm-level data from five Euro area countries, Belke et al. (2015) find that domestic demand developments are relevant for the short-run dynamics of exports especially during the more extreme stages of the business cycle. A strong substitute relationship between domestic and foreign sales can most clearly be found in Spain, Portugal and Italy, providing evidence of the importance of sunk costs and suggesting that history matters in international trade. In their analysis of Chilean firms, Blum et al. (2013) find that intermittent exporters have lower capital (either given exogenously or related to their lower productivity): as a consequence the marginal costs of exporting is higher when domestic demand is 
high since it is more profitable to sell domestically. When domestic demand is low it becomes more profitable to sell to foreign markets, and as a result firms reduce domestic sales and start exporting.

Given these theories and evidence, we argue that firms' export exit may reflect the adjustment to external market conditions, including both domestic and overseas market conditions. It is a process of firms' learning through engaging in international export markets and at the same time identifying and creating opportunities. Profitable opportunities encourage entry, into either the domestic market or global markets. When the domestic market grows, exporters may find higher profit margins from domestic sales increase and hence are willing to shift sales from exports back to the home market. Similarly, when global markets grow, selling in international markets becomes more profitable, hence staying in export markets and expanding the market share is logical.

Hypothesis 1a: The higher the growth rate in the domestic market, the more likely are firms to exit export markets.

Hypothesis 1b: The higher the growth rate in foreign markets, the less likely are firms to exit export markets.

\section{The Role of Internal Resources}

The outcome of the knowledge gained from exporting can be to withdraw commitment from international markets, just as much as it is possible to increase resource commitment. Firms may realize only after starting to export, or only through exporting, that they are not competitive enough to stay in international markets: negative performance feedback therefore leads such firms to cease exporting. An example of this arises in 'opportunistic' or 'accidental' exporters, firms which may respond to an enquiry or order placed by a customer overseas without such behavior being a clear strategic decision (Crick, 2003; Requena-Silvente, 2005). Such firms may not have sufficient time to learn about foreign markets and that may induce their rapid exit from exporting. By contrast, more resourceful and capable firms are more likely to be in the position to survive the negative productivity shocks than less resourceful and capable ones.

This suggests that the nature of a firm's response to changes in domestic and foreign demand will be determined partly by its internal resource capabilities. We therefore hypothesize that firms' internal characteristics and resources interact with market conditions in systematic ways to determine the likelihood of exit.

Although expanding foreign markets provide opportunities for all firms (as H1b above suggests), for small firms this is something of a mixed blessing. Smaller firms and those further from the productivity frontier are less likely to be able to compete effectively with the increased competition that is likely to accompany increased foreign demand. Such marginal firms may find themselves squeezed out of export markets as their (relative) productivity levels fall relative to the average, as new, more capitalintensive and more productive entrants move into the market. Similarly, smaller and less productive firms are more likely than larger, more capitalintensive and more productive enterprises to exit export markets when domestic demand rises. Such firms are more likely to be 'opportunistic' exporters: for them exporting is often a marginal exercise, and one which is easily reversed when domestic demand conditions improve relative to export markets. Precisely such a scenario is outlined by Crick (2003), and demonstrated for British new technology-based firms by Love and Ganotakis (2013). And in their analysis of Chilean firms, Blum et al. (2013) find that intermittent exporters tend to have lower capital intensity, possibly related to their lower productivity. By contrast, larger and more productive firms are less likely to be adversely affected by increased demand in expanding export markets, and are also more able to cope with increased production in times of rising domestic demand without the need to switch out of export markets, an option which may be more difficult for smaller firms and those further from the productivity frontier. In addition, larger and more capital-intensive firms may suffer from a degree of inertia or sclerotic thinking as well as having longer-term planning horizons than their smaller, more nimble counterparts, making them less reactive to short-term changes in demand conditions. This leads to our next hypothesis:

Hypothesis 2a: The larger the firm, the less strongly it reacts to changes in domestic and foreign demand in terms of the likelihood of export exit.

Hypothesis 2b: The more productive the firm, the less strongly it reacts to changes in domestic and foreign demand in terms of the likelihood of export exit. 
Hypothesis 2c: The more capital-intensive the firm, the less strongly it reacts to changes in domestic and foreign demand in terms of the likelihood of export exit.

\section{Export Re-Entry: Firm Resources and External Market Conditions}

The key distinguishing feature of intermittent exporters is that they re-enter exporting having previously ceased doing so. As with the exit decision, we postulate that re-entry will depend on firms' internal productive resources and on their strategic reactions to domestic and foreign demand conditions.

There is evidence that experience of exporting helps firms to learn about and overcome the difficulties of operating in foreign markets (Salomon \& Shaver, 2005; Love \& Ganotakis, 2013; Sui \& Baum, 2014). In particular, the past experience of exporting reduces the uncertainty associated with re-entering export markets and helps firms lower the sunk cost associated with re-entry. This is consistent with the view that previous international experience leaves international 'heritage' which can be useful for subsequent re-entry (Welch \& Welch, 2009).

However, firms will vary in their capacity to access, interpret and absorb the information gained through a previous period of exporting. Firms with a low probability of exiting exporting, typically larger, more productive enterprises, will typically find the same attributes useful in re-entering should the need arise: we know from the export entry literature how important scale and productivity are in entering foreign markets. In addition we argue that the firms best equipped to absorb useful knowledge from their previous exporting experience are those which already have the scale, productive capacity and absorptive capacity to learn - precisely the set of firms which had a relatively low likelihood of exit. While some larger firms may suffer from inertia or sclerotic thinking, recent evidence indicates this is largely a function of firm age rather than size, while scale and previous experience are major advantages in export entry and success (Love, Roper, \& Zhou, 2016). Thus variations in firms' internal resources not only directly affect exit, but have a conditional effect on the probability of re-entry: exit and reentry are inversely correlated.

\section{External Market Conditions}

Related to Hypothesis 1a and 1b on exit, we argue that the external market conditions in which exporters exited exporting not only help explain the exit decision, but also matter with respect to the likelihood of re-entry. This is because the reasons for exit say much about the quality of firm's internal resources and the nature of the export re-entry. On the one hand, when the domestic market experiences a boom, firms face increasing marginal costs of exporting as it is more profitable to sell domestically and output is fixed in the short term (as in Blum et al., 2013). Firms that have suitably high productive capacity may not need to choose the domestic market over foreign markets, and are able to expand in the domestic market while remaining as exporters. However, firms that have short-term quantity constraints in the amount of output that they can produce may decide to retreat (temporarily) from the foreign market to satisfy increased domestic demand. Subsequently such firms are more likely to increase production in the following periods not only to meet the increased demand domestically, but also to re-start selling abroad.

On the other hand, if firms exit exporting when the domestic market experiences a negative shock (such as an economic crisis), then it is reasonable to assume that they might be experiencing challenges in maintaining sufficient profit margins to stay in export markets. A likely scenario is that the firm is heading towards closure: Ilmakunnas and Nurmi (2010) show that many exporting firms share similar characteristics to those of firms completely exiting from the market. Such firms are hence less likely to re-enter export markets.

Similarly, when foreign markets experience a boom, irrespective of domestic market conditions, firms face lower marginal costs of exporting, as it is more profitable to expand international market and sell less domestically. Under these conditions it is counter-intuitive to retreat from exporting unless firms experience serious challenges in maintaining sufficient profit margins to stay in foreign markets. One possible scenario is that a positive global demand shock encourages new entrants to compete in the existing markets. Increased competition decreases profit margins for incumbents, and some of the existing exporters may no longer be able to continue exporting. If exit from exporting is driven by the exporter's insufficient productive efficiency, it may take time to catch up with the productivity frontier: thus firms which exited when foreign demand was growing are in a relatively weak position to subsequently re-enter exporting. Hence: 
Hypothesis 3a: The higher the domestic market growth rate at the time of exit, the more likely firms are to re-enter exporting.

Hypothesis 3b: The higher the foreign market growth rate at the time of exit, the less likely firms are to re-enter exporting.

Together, Hypotheses $1 \mathrm{a} / 1 \mathrm{~b}$ and $3 \mathrm{a} / 3 \mathrm{~b}$ indicate that reactions to demand conditions at the time of exit systematically affect the probabilities of both exit and re-entry. Coupled with the other hypotheses, this in turn suggests a clear pattern of the nature and likelihood of intermittent exporting under different demand conditions at the time of exit. These are illustrated in Fig. 1, which compares the situations when domestic and foreign demand are high/low at the time of exit.

In the top left quadrant, where demand growth is (relatively) high in the domestic market but (relatively) low in overseas markets, domestic and foreign conditions pull in the same direction with regard to exit/re-entry: firms clearly have an incentive to exit exporting on both counts. As indicated in $\mathrm{H} 3 \mathrm{a} / 3 \mathrm{~b}$, firms exiting under these conditions also have a high likelihood of subsequent re-entry: firms that have short-term quantity constraints in the amount of output that they can produce may decide to retreat (temporarily) from the foreign market to satisfy increased domestic demand. Such firms are able to increase production in the following periods to re-start selling abroad when demand conditions improve. Under these conditions, exit and re-entry is therefore likely to be relatively

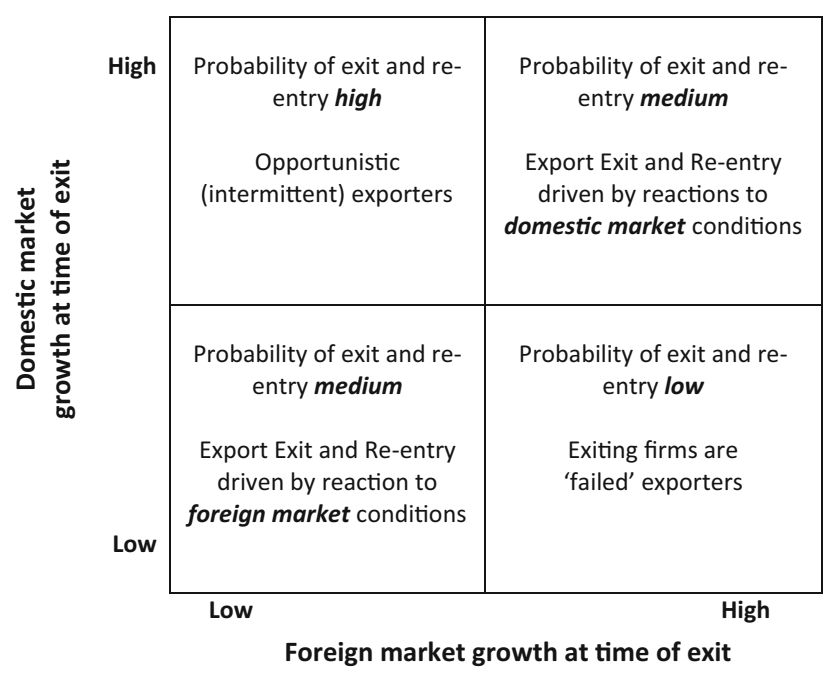

Figure 1 Market growth conditions and probability of export exit and re-entry. frequent: firms reacting this way may be characterized as the opportunistic intermittent exporters, frequently relatively small-scale producers which react strongly to changes in demand at home and abroad (H2a).

On the leading diagonal are conditions where demand in both domestic and foreign markets is high/low at the time of exit. Here, conditions in either the domestic or export markets drives exit and re-entry patterns. In the high/high case (top right quadrant) any incentive to exit comes exclusively from reaction to the growth in the domestic market, as some firms switch production there in the short term (H1a). These firms are also likely to re-enter exporting (H3a) as they are subsequently able to expand production to accommodate growth in both domestic and overseas markets. Thus intermittent exporting takes place, but is driven wholly by reactions to events in the domestic market. In the opposite low/low growth case (bottom left quadrant) the reverse applies: exit and reentry occurs as a result of firm's responses to low demand growth in export markets. Firms thus have an incentive to exit exporting, but they are also in a good position to re-enter exporting subsequently. This is because they left exporting purely because of low demand, and were not driven out by the competition in export markets.

The final case is where domestic market growth at the time of exit is low, and that of export markets at the time of exit is high. Firms have little incentive to exit exporting here, but those that do are illequipped for re-entry into exporting: these firms exit exporting because they are unable to keep up with the competition in growing export markets, not because of limited export opportunities. The likelihood of intermittent exporting is therefore low, and firms exiting under these conditions might best be regarded as 'failed' exporters.

\section{DATA AND METHODS}

France has a large exposure to international trade, a large domestic market and a well-developed manufacturing sector; hence it represents the ideal setting to test our hypotheses. In addition, France shares its borders with the largest economies of the Euro area and it has close linguistic and cultural ties with some of its neighboring countries such as Belgium, Switzerland and parts of Germany. These factors favor the diffusion of export intermittency across French companies, because bordering countries are the most prevalent export destinations 
among non-permanent exporters (Eaton, Kortum, \& Kramarz, 2004), and common language, similar culture and currency further reduce the barriers to trade with these countries (Egger \& Lassmann, 2015).

We can test our hypotheses using a longitudinal firm-level dataset covering almost the entire population of French firms observed over the period 1997-2007. Our dataset is based on data sourced from the Fichier complet de Systeme Unifie de Statistique d'Entreprises (FICUS) database that is provided by the French National Statistical Office (INSEE). Data from FICUS are mostly based on firms' fiscal declarations, and they provide accurate information on a number of balance sheet items. The wide coverage of FICUS, and the wealth of information on individual firms that it provides, permits the tracking of French firms' demography, exporting activities, and performance indicators with an unusual level of detail. ${ }^{3}$ The relatively long period of time covered by our dataset also allows us to overcome one of the most common limitations of micro-level datasets that prevent tracking the export behavior of firms over time.

We restrict our analysis to the manufacturing sectors. ${ }^{4}$ Although manufacturing firms constitute only about $10 \%$ of the population of French companies, we calculate that they nevertheless account for over $60 \%$ of total French exports as reported by the firms in the dataset. The focus on manufacturing firms is a common feature of the empirical trade literature and it is in line with the objective of studying the strategy of companies that are both involved in the production and in the sales of their output.

In each period, exporters are identified as companies reporting a positive value of foreign sales. Table 1 describes the composition of the dataset by export status over the period 1997-2007. Approximately 200,000 manufacturing firms are observed every year, and the number of exporters ranges from a minimum of 36,873 in 1997 to a maximum of 46,473 in 2000 . In 2000 , the number of firms that enter into the export market $(12,734)$ is much larger than in other years (about 6000). In addition, since 2001 the number of firms that exit the export markets is larger than in previous periods. Both the massive entrance of new exporters in 2000 and the higher number of exits in following periods are consistent with the idea that the introduction of the Euro increased the export entry of smaller companies that are also more likely to quit exporting. More importantly for our study, the significant numbers of firms that enter and exit the export market suggest that we may exploit firm-level variations in export status to test our hypotheses.

\section{Methodology}

A possible approach to identify intermittent exporters is to split the sample of firms into categories such as 'intermittent' and 'continuous' exporters on the basis of pre-defined patterns of export participation observed during the period of the analysis. By definition, such an approach involves some arbitrary decisions. For example, to identify intermittent exporters it is necessary to choose the minimum length of each exporting and nonexporting spell that distinguishes intermittent exporting from other forms of exporting behavior. Regardless of the argument made to justify any chosen definition of intermittency, this approach restricts the validity of the analysis to the period in which firms are observed in the dataset. For example, a company exiting and re-entering the export market during the period of the analysis may behave as a continuous exporter if observed in previous or later periods.

Our investigation does not rely on a discretionary typology of export intermittency: instead, we study how firm-level characteristics and demand variations concur in determining an exporter's retreat to the domestic market and its subsequent re-entry into the export market. In practical terms we first model a firm's probability of leaving the export market and then estimate a second model aimed at identifying which factors facilitate the re-entry of those firms that previously exited the export market. By modeling explicitly export exit and re-entry our results are less sensitive to the definition of export intermittency, although clearly the sample of firms that we observe re-entering the export market is inevitably dependent on the time window of our dataset. However, we argue that the 11-year period covered provides a sufficiently long time span to capture a representative sample of intermittent exporters.

To operationalize this strategy, the analysis proceeds in two steps. We first estimate a Probit model of export exit where the dependent variable is the bivariate variable Exit $t_{i t}$ that assumes value one in the year $t$ in which an exporter $i$ exits the export market. The period of exit is defined as the first period with no foreign sales. ${ }^{5}$ This model is estimated on a sample including exporting firms observed from the first year they enter the dataset (or the first year they are observed exporting) until 
Table 1 Composition of dataset by export status

\begin{tabular}{|c|c|c|c|c|c|c|}
\hline Year & Firms & Exporters & Export entries & Export exits & $\begin{array}{l}\text { Domestic sales } \\
\text { (mean) '000 euros }\end{array}$ & $\begin{array}{l}\text { Foreign sales } \\
\text { (mean) '000 euros }\end{array}$ \\
\hline 1997 & 202,082 & 36,873 & - & - & 3308 & 946 \\
\hline 1998 & 212,583 & 38,163 & 5481 & 4611 & 3424 & 1010 \\
\hline 1999 & 212,381 & 38,040 & 5137 & 4874 & 3803 & 1054 \\
\hline 2000 & 206,896 & 46,473 & 12,734 & 4613 & 3916 & 1134 \\
\hline 2001 & 197,391 & 44,933 & 6651 & 6848 & 4226 & 1250 \\
\hline 2002 & 204,980 & 45,198 & 6627 & 6877 & 4503 & 1244 \\
\hline 2003 & 202,873 & 44,518 & 6649 & 6390 & 4551 & 1262 \\
\hline 2004 & 203,235 & 44,370 & 6363 & 6207 & 4729 & 1300 \\
\hline 2005 & 191,308 & 42,913 & 6190 & 6266 & 4375 & 1284 \\
\hline 2006 & 202,373 & 43,345 & 6198 & 6006 & 4389 & 1379 \\
\hline 2007 & 198,070 & 42,664 & 6167 & 6219 & 4560 & 1446 \\
\hline
\end{tabular}

Source: FICUS.

the occurrence of their first observed export exit. Table 2 reports the number of unique exporters by the length of the first export spell observed (number of years): 'exiters' are those we observe exiting the export market at some point in time between 1997 and 2007, while 'non-exiters' are those that keep exporting throughout the period they appear in the dataset. The distinction between non-exiters and exiters is important because only the latter group of firms enters in the estimation sample that we use in the second step.

The second step of our analysis investigates the role of firm-level attributes and demand conditions in determining re-entry into exporting. We therefore estimate a second Probit model for those firms that previously exited the export market. Some of the firms included in this second sample are observed re-entering the export market before 2008 (i.e., 're-entrants') while others continue as non-exporters until the end of the observation period (i.e., 'non-re-entrants' - see Table 3). The

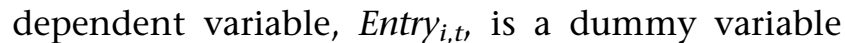
assuming value one for the period in which the firm re-enters exporting and value zero otherwise.

\section{Independent Variables}

To test our hypotheses both estimations contain independent variables reflecting firm resources and demand conditions in both domestic and foreign markets. The relevant variables are now explained in turn.

The variables for firm's internal resources include measures of size, technology, and performance. Firm productivity is measured by total factor productivity $T F P_{i, t}$. This is obtained as the residual from the estimation of a production function by the Levinsohn-Petrin method (Levinsohn \& Petrin, 2003). ${ }^{6}$ We control for a firm's technology by the inclusion of capital intensity $K_{i, t}$, that is computed as the natural log of a firm's book value of tangible assets per employee. Lastly, we proxy for a firm's size by the log number of employees Employ E $_{i, t}$.

Table 2 Population of potential export exit firms

\begin{tabular}{lccr}
\hline First export spell (years) & Number of exporters & Number of non-exiters & Number of exiters \\
\hline 2 & 29,297 & 6705 & 22,592 \\
3 & 14,349 & 5303 & 9046 \\
4 & 9156 & 4030 & 5126 \\
5 & 6481 & 2982 & 3499 \\
6 & 4945 & 2596 & 2376 \\
7 & 4161 & 2553 & 1608 \\
8 & 4214 & 2954 & 1260 \\
9 & 2711 & 1790 & 931 \\
10 & 2761 & 2078 & 683 \\
11 & 12,073 & 11,559 & 514 \\
Total & 90,148 & 42,513 & 47,635 \\
\hline
\end{tabular}


Table 3 Population of potential export re-entry firms

\begin{tabular}{lccr}
\hline First export spell (years) & Number of exporters & Number of non-re-entrants & Number of re-entrants \\
\hline 2 & 6467 & 3867 & 2600 \\
3 & 5963 & 2953 & 3010 \\
4 & 5535 & 2312 & 3223 \\
5 & 5147 & 2109 & 3038 \\
6 & 4364 & 1751 & 2613 \\
7 & 2949 & 918 & 2031 \\
8 & 2388 & 771 & 1617 \\
9 & 1168 & 491 & 677 \\
Total & 33,981 & 15,172 & 18,809 \\
\hline
\end{tabular}

The variables $\Delta D_{0 m}, t$ and $\Delta$ For $_{s, t}$ respectively proxy the demand conditions faced by a firm in the domestic and in the foreign market. $\Delta D_{0 m_{s, t}}$ measures year-to-year variations in domestic demand as the log difference between sectoral absorption in France (i.e., domestic production plus exports minus imports) between two consecutive years for the aggregate output of the two-digit ISIC industry of the firm. ${ }^{7}$ Positive and negative year-to-year variations respectively indicate expansions and contractions of the domestic market. Similarly $\Delta F o r_{s, t}$ is the log difference in the aggregate sectoral absorption across the countries sharing a border with France. We proxy foreign demand with the demand of bordering countries only because previous research shows that firms first expand into geographically close export markets and then target more distant export destinations (Eaton et al., 2004). Hence we expect neighboring countries' demand to affect more directly the export decisions of potentially intermittent exporters.

The re-entry Probit model contains additional variables that describe the demand conditions in the domestic and in the foreign market in the year when firm $i$ left the export market $\left(\Delta D o m_{s, 0}\right.$ and $\Delta$ For $_{s, 0}$ respectively). The inclusion of these variables is intended to capture the different probability of re-entering into exporting across firms that left the export market under different demand conditions. For example, it is possible that a firm that leaves the export market when domestic demand is booming is following a different export strategy from a firm leaving the export market when domestic demand is stagnant, a key component of $\mathrm{H} 3 \mathrm{a}$ and $\mathrm{H} 3 \mathrm{~b}$.

The re-entry model also contains the term $I M R_{0}$, the Inverse Mill's Ratio computed on the basis of the estimated coefficients obtained from the model on export exit. This term corrects for any bias arising in the re-entry model due to the correlation between firm-specific, time-invariant factors that determine both the termination of the first export spell and the probability of export re-entry.

In both models we include two conditioning variables. As a standard indicator of a firm's vintage we use the variable $A g e_{i, t}$, the log number of years since the establishment of the firm. ${ }^{8}$ Finally, $s_{i}$ is the $(\log )$ of the length of time a firm exports (in the exit model) or does not export following exit (in the re-entry model).

Summary statistics and correlation coefficients for the key variables are shown in the Appendix. A more technical discussion of the estimation process is contained in the Web Appendix.

\section{RESULTS}

This section reports the empirical results of our analysis and discusses the findings. We first focus on the results of export exit, which test Hypotheses 1 and 2. They are also instrumental to the following analysis focusing on export re-entry, which directly tests Hypothesis 3.

\section{Export Exit}

Table 4 reports the estimated marginal effects of the determinants of export exit. The baseline regression model, as listed in Column (1), delivers largely consistent estimates with our expectations built upon the conceptual framework. The negative signs of firm size, TFP and capital intensity suggest that bigger, more productive, more capital intensive firms are less likely to exit exporting, ceteris paribus. This also confirms the predictions in the literature on symmetry in the determinants of export entry and exit (Wagner, 2008; Ilmakunnas \& Nurmi, 2010).

Turning to examining the role of external market conditions in driving export exit decisions, we 


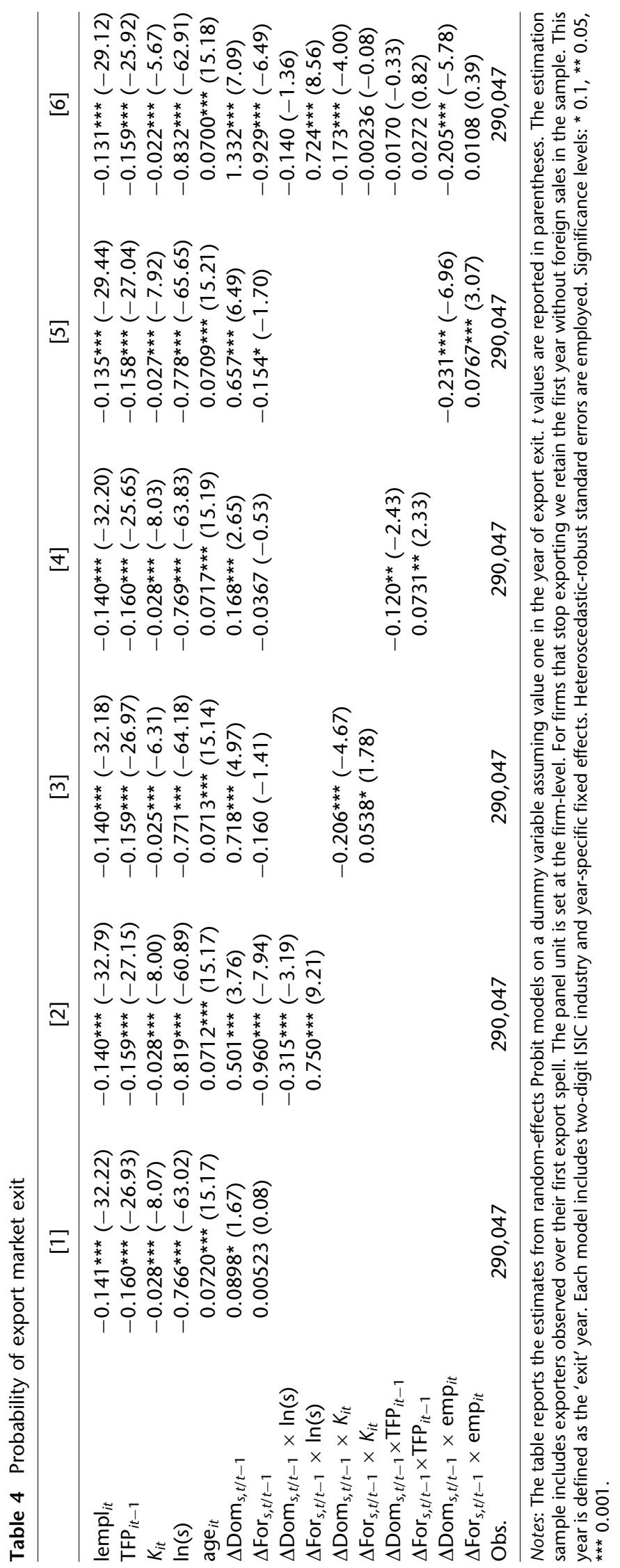


experiment on introducing their influence gradually, by first only including in the model the linear terms of domestic market conditions and international market conditions. The results in Column (1) suggest that on average, domestic market expansion increases the likelihood of export exit, consistent with H1a. However, this specification does not find that demand conditions in the foreign market have any effect on the probability of export exit.

Column (2)-(6) extend the analysis to allow for market conditions being moderated by firms' internal resources $(\mathrm{H} 2)$. We interact one set of individual firm characteristic with domestic and international market changes at a time, and finally allow them to enter the estimation together. Interestingly, the marginal effects of the interaction terms are generally statistically and economically significant, while the marginal effects of the market condition variables ( $\triangle D o m$ and $\Delta F o r$ ) change noticeably depending on which interaction terms we include in the model. This is particularly true of the response to changes in foreign demand, suggesting that while firms' exit decisions are affected by domestic market conditions across all firms, firm-specific characteristics determine the impact of foreign market conditions. Put differently, exporting firms commonly respond to changes in domestic demand, but only specific types of firms tend to respond to changes in foreign demand.

Turning to Column (6), our main model specification, four clear results emerge. First, domestic market growth increases the probability of firms' exiting export market. This is consistent across all model specifications. Second, firms are generally less likely to exit exporting when foreign markets experience growth. Hence our Hypotheses 1a and $1 \mathrm{~b}$ are supported. These findings show that exporters adjust their export decision to external market conditions. Exporters with restricted production capacity tend to return to domestic markets when domestic demand is high, for higher profit margins. On the contrary, firms are unlikely to stop exporting when international markets are flourishing.

Third, firm variations in firms' internal resources play an important moderating role in these effects. Smaller, less productive and less capital-intensive firms appear to respond to market changes more strongly, from both domestic and international markets, supporting $\mathrm{H} 2$. This is not difficult to understand, in that these firms are more likely to be opportunistic and may actively seek market opportunities and hence react to circumstances more flexibly (Love \& Ganotakis, 2013). Another explanation is that compared to these firms, the larger, more capital-intensive counterparts take longer to alter their strategies and hence are unable to react to market changes right away.

Finally, we also find that the longer a firm stays in export market, the less likely it is to exit exporting (the coefficient on $\ln (s)$ is negative and significant). This is the case even after other resource effects are allowed for: firms are more likely to overcome the liability of foreignness if they have stayed in export markets longer. In addition, the probability of exit increases with age, complementing recent findings that age has a negative effect on exporting performance (D'Angelo, Majocchi, Zucchella, \& Buck, 2013).

\section{Export Re-entry}

Building on the findings on export exit, we move to export re-entry models. Table 5 reports the six sets of regression estimates of marginal effects. As before, we start by only including only linear market condition terms without interaction terms (Column (1)), and then gradually include one set of interactions at a time (Columns (3)-(5)), and finally arrive at the final model specification as reported in Column (6).

The first thing to note is that the IMR is consistently statistically significant across all model specifications. The fact that the coefficient sign is consistently negative offers support for the intuition that firms with a low probability of exit have a higher probability of re-entry into exporting. Formally, the IMR captures the correlation between the unobserved firm heterogeneity in the export exit estimation and the unobserved firm heterogeneity in the export re-entry estimation. Hence factors that prevent firms from dropping out of export markets - and which have not been accounted for in our exit model - also encourage firms to re-enter the export market. Although our data and model cannot (by definition) identify these unobserved firm-specific characteristics, the existing literature provides room for imagination about possible factors, such as management experience and capability (Ganotakis \& Love, 2012), production networking effects (Bertrand, 2011), and differential international strategies (Sui \& Baum, 2014).

Paralleling the exit results, we also find that the longer the period since a firm's export exit, the less likely it is to re-enter exporting, indicating that the knowledge obtained from export experience has a limited shelf-life and is liable to atrophy if not 


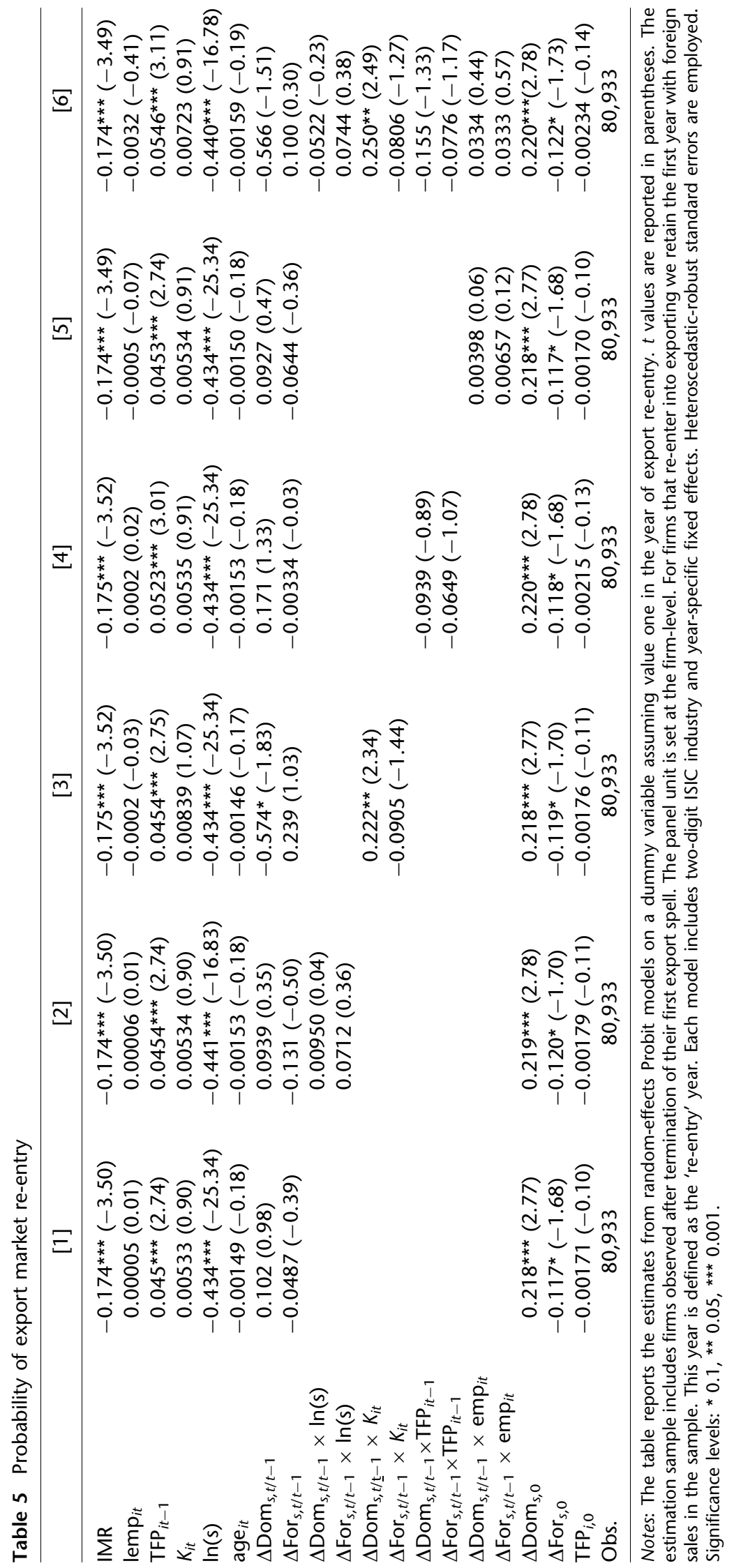


used. ${ }^{9}$ The other obvious pattern in Table 5 is that we observe far less impact of firm characteristics on firm re-entry compared to their prominent roles in determining the export exit decision. Given the abundant literature on firm export entry (Wagner, 2008), this finding makes an interesting contrast with the crucial role of firm resources in determining export entry. Our results imply that while variations in internal resources also matter in determining exit (Table 4), they have less predictive power to explain export re-entry once the conditional nature of previous export exit is controlled for through the IMR variable. ${ }^{10}$

Shifting our attention to market condition variables, we find the recent changes in market conditions do not have statistically significant impacts on re-entry. This is in marked contrast to the results for exit, where market conditions played a key role. What does appear rather important for re-entry, however, are the market conditions the firm experienced at the time of export exit $\left(\Delta D_{0} m_{0}\right.$ and $\left.\Delta F o r_{0}\right)$. To be more exact, domestic market growth at the time of the previous export exit has a strong and consistent positive effect on the probability of firms' export re-entry. Growth in international markets at the time of exit is associated with a reduced probability of export re-entry. This result shows that the reasons for export exit help explain the likelihood of export re-entry, supporting H3a and $\mathrm{H} 3 \mathrm{~b}$. This also accords with the findings of Lin (2014) that greater irregularity in the pattern of internationalization (i.e., more intermittent exporting) is linked to relative performance in domestic and export markets.

\section{ROBUSTNESS CHECKS}

To check the robustness of our results we carried out three extensions to the analysis. First, we re-ran our analysis using a broader definition of foreign market demand which employed a weighted average of all French export markets rather than demand in countries sharing a border with France. Second, we checked for the effects of potential endogeneity arising from the possibility that the set of variables capturing firm resources (employment size, capital intensity and productivity) could be correlated with firms' unobserved factors subsumed in the Probit equations error terms. Finally, we checked our results for the possibility that firms switching out of exporting to other forms of internationalization (e.g., FDI) could partly explain our results. In all cases the additional econometric analysis produced results qualitatively indistinguishable from those presented in Tables 4 and 5 . These results, and a more extensive discussion of the robustness testing procedure, can be found in the accompanying Web Appendix.

\section{DISCUSSION AND LIMITATIONS}

Intermittent exporting is something of a puzzle. In the theoretical literature in both economics and international business, exporting represents a major commitment available only to the most productive and best-resourced firms, and is often the starting point for further internationalization. In practice, however, there is evidence from numerous countries of firms engaging in intermittent exporting, moving into and out of exporting, sometimes on more than one occasion. Since intermittent exporting involves export exit and re-entry, and since the re-internationalization process is relatively poorly understood (Welch \& Welch, 2009), there is merit in focusing attention on the empirics of the exit and (conditional) reentry process. We do this for an extensive dataset of French manufacturing firms over the period 1997-2007.

Our empirical analysis produces a number of key findings. Unsurprisingly, smaller and less productive firms are more likely to exit exporting than their larger, more productive counterparts. However, domestic and overseas market conditions matter greatly here. While growth in demand affects all firms in systematic ways, smaller and less productive firms react much more strongly to changes in both domestic and foreign market growth than larger firms. Coupled with the finding that the longer a firm remains in exporting the less likely it is to cease doing so, this suggests that smaller firms, especially those with limited experience of exporting, are more likely to be opportunistic in moving out of export markets as demand conditions vary (Crick, 2002; Love \& Ganotakis, 2013). While larger, better resourced firms have less need to exit exporting as market conditions vary, inertia and sclerosis may also play a part here. Larger and (especially) older firms are more likely to suffer from inertia in the form of both a slower recognition of a need for change and a slower response to such a need (Love et al., 2016), which may in part explain their less nimble behavior.

There are three key finding on export re-entry. First, those firms with a low exit probability also 
have a high likelihood of re-entry, and vice versa. However, once this conditional link between entry exit and re-entry is accounted for, characteristics such as size and capital intensity lose their importance: put simply, once a firm leaves exporting, merely being large or capital intensive won't help it get back into export markets (although being highly productive will help). The second key finding is that conditions in domestic and foreign markets around the time of re-entry have little effect on the probability of re-entry. This is in sharp contrast to the situation on export exit, described above. However, the third finding is that market conditions at the time of exit - and how the firm reacted to these - matter greatly in determining the likelihood of re-entry. Specifically, firms that stop exporting when the domestic market is growing are more likely to re-enter later, while firms that stop exporting when export markets grow are less likely to start exporting again. Crucially, our results strongly support the predictions of the effects of different domestic/export market growth rates summarized in Fig. 1.

Taken together, these findings highlight the role of the firm's strategic choice in exit and re-entry, especially with regard to the reaction to changes in demand at both home and abroad. Our other empirical results further support and clarify the predictions of Fig. 1, and in particular shed light on the opportunistic and intermittent nature of exporting among small firms, a feature observed but largely unexplained in earlier research (e.g., Crick, 2004; Love \& Ganotakis, 2013). Small firms react more strongly than larger firms to changes in demand patterns in terms of exiting export markets because they are able more quickly to shift production to areas of growth. This may mean moving out of exporting completely when the domestic market grows rapidly, and performance in exporting is (relatively) less profitable. However, they are also able to re-enter exporting at short notice, as long as they are above the threshold level of productivity and have the management capacity to be competitive at the fringes of exporting. Indeed, for at least some small firms moving into and out of export markets may not be a coherent strategy at all. They may become exporters almost by default as a result of unsolicited export orders, and simply act entrepreneurially to market opportunities as they present themselves, without consciously distinguishing between domestic and export markets (Love \& Ganotakis, 2013). Our results show clearly that this form of behavior is most likely to occur among relatively small firms and when domestic demand is growing relative to overseas market growth, giving rise to the opportunistic intermittent exporters shown in the top left quadrant of Fig. 1. To the best of our knowledge the nature this interplay between firm characteristics and market demand patterns has not been clearly documented previously.

\section{Theoretical Implications}

Our findings have a number of implications for theory. First, internationalization is not irreversible, at least as far as exporting is concerned. A simple examination of the raw data demonstrates that a significant proportion of manufacturing firms enter and exit exporting each year. The data are particularly striking on exit: for the FICUS data, on average around $14 \%$ of firms that had previously exported ceased doing so in any given year (Table 1). In addition, over the eleven years of our dataset, around half of exporters exited exporting at least once (Table 2), and over half of those subsequently re-entered exporting (Table 3). This suggests that for a substantial proportion of French manufacturers exporting is at best a temporary activity. While this is not necessarily incompatible with the process model of internationalization (Johanson \& Vahlne, 2009) - intermittent exporting could be a stage into a more persistent exporting pattern - it does suggest that the simple dichotomy of firms into 'exporters' and 'non-exporters' is unhelpful or at least insufficient in both conceptual and empirical terms. Many firms - especially small firms - inhabit an area between these two categories, in which opportunistic, intermittent and even accidental exporting is commonplace. As indicated in the conceptual section above, theoretical conceptions of (small) business internationalization typically do not explicitly allow for or explain this grey area of internationalization, suggesting an area for further theoretical consideration.

Second, there is a clear need to pay attention to both external (demand) conditions as well as internal firm resources in considering export exit and re-entry. Crucially, this relates not simply to conditions in (potential) export markets, but also conditions in the domestic market. Unlike the RBV which focuses on the internal resources of the firm, the process model of internationalization does consider the nature and scale of foreign markets, and the need to develop experiential knowledge of potential new markets (Johanson \& Vahlne, 1977, 2009). However, the focus in the process 
model is very much on the potential foreign market. Our analysis indicates that domestic market conditions are equally important in the decision to exit and/or re-enter export markets, especially with regard to small and less capitalintensive firms. Importantly, the interaction between market conditions and firm's internal resources matters here, especially with regard to the export exit decision.

Third, and most importantly, our analysis demonstrates how closely interlinked are exit and re-entry, but in ways not previously acknowledged. Both the firm characteristics and the external demand conditions which are present at the time of exit are crucial determinants of the probability of re-entry: why and how firms came to the decision to exit are crucial determinants of the re-entry decision. Most importantly, we have identified theoretically, and confirmed empirically, the demand conditions under which intermittent exporting is most likely to occur, and the firm attributes most likely to give rise to such behavior. Welch and Welch (2009) suggest that previous episodes of internationalization leave a heritage of experience which may help or hinder future attempts to re-enter international markets. Our findings support this view within the confines of exporting behavior, and indeed indicate that any analysis of export re-entry must consider the rationale for the earlier exit decision.

Finally, our analysis indicates that firm age is a poor proxy for international experience. Some studies still use firm age as a proxy for the duration of firms' internationalization (e.g., Majocchi, Bacchiocchi, \& Mayrhofer, 2005; D'Angelo et al., 2013), implicitly assuming that age automatically reflects international experience. However, we find strong evidence that while firm age is positively associated with the likelihood of exit, the length of time a firm has been exporting has a highly negative effect on the probability of export exit: in addition, age has no effect on the likelihood of re-entry, while the length of time out of exporting is strongly inversely correlated with re-entry. In terms of export entry and exit, age and firm experience are different attributes, and one is a poor proxy for the other (Love et al., 2016).

\section{Limitations}

As with all empirical analysis, our research is subject to a number of limitations, some of which provide opportunities for further research. Although very extensive, our data relate to firms from one country
(France), and to manufacturing only. It seems likely that conclusions drawn from French data are reproducible for other large, open economies, but we cannot preclude the possibility that there are peculiarities of French exporting behavior that are unique to that country. We restrict our analysis to manufacturing, and do not consider trade in services. However, we regard this as a strength rather than a limitation, as exporting in services has its own peculiarities and differences from trade in manufactured goods which often requires separate consideration (Love \& Mansury, 2009).

Necessarily, the FICUS data are restricted to variables available from financial statements, and exclude information on aspects such as the internal capability of management and firm strategy. These important considerations are relegated to unobserved heterogeneity in our analysis: while we believe this is more than compensated for by the extensive nature of the FICUS data, in terms of both firm numbers and timescale, it is a limitation of using official secondary data that must be acknowledged. For example, we are able to say nothing about the decision processes that lead some firms to adopt intermittent exporting, and therefore cannot shed light on the extent to which it represents a conscious strategy as opposed to an opportunistic reaction to circumstances. Further detailed research on this would undoubtedly be revealing, especially on the ways in which the strategic rationale for exit has a role to play in the export re-entry decision. We are also limited in the lack of information on alternative internationalization modes. Although the robustness checks indicate that our findings are unlikely to be driven by firms switching to alternative modes of market entry, the precise role of alternative forms of internationalization remains unclear: the link between intermittent exporting and the decision to engage in, for example, FDI would appear to be an area of potentially fruitful research. Finally, the timing of our data just precedes the financial crash of 2008. Given that financial health and exporting are closely linked among French firms (Görg \& Spaliara, 2014), this episode may well have resulted in changes in the export performance of many firms.

\section{ACKNOWLEDGEMENTS}

We would like to thank Diane Tchawa for providing research assistance and executing the Stata programs at the GREDEG laboratory in Nice. 


\section{NOTES}

${ }^{1}$ For a summary of this literature see Ganotakis and Love (2012).

${ }^{2}$ Hashai and Almor (2004) show that knowledgeintensive firms that appear to be 'born global' do in fact go through an internationalization process rather similar to that of larger MNEs.

${ }^{3}$ FICUS excludes only firms with fewer than 10 employees and revenue below 81,500 euros for manufacturing or below 32,600 euros for services. All values reported in this dataset are in thousands of euros and they are deflated using two-digit industry specific indices provided by INSEE for consumer, value added and capital prices.

${ }^{4}$ Manufacturing firms have their economic activity falling within sectors $15-37$ of the ISIC Rev. 3 classification.

${ }^{5}$ The implications for our definition of exit of switching to other forms of international activity are explored in the robustness checks section below.

\section{REFERENCES}

Barney, J., Wright, M., \& Ketchen, D. J. 2001. The resourcebased view of the firm: Ten years after 1991. Journal of Management, 27: 625-641.

Belke, A., Oeking, A., \& Setzer, R. 2015. Domestic demand, capacity constraints and exporting dynamics: Empirical evidence for vulnerable euro area countries. Economic Modelling, 48: 315-325.

Bertrand, O. 2011. What goes around, comes around: Effects of offshore outsourcing on the export performance of firms. Journal of International Business Studies, 42: 334-344.

Blum, B. S., Claro, S., \& Horstmann, I. J. 2013. Occasional and perennial exporters. Journal of International Economics, 90: 65-74.

Bonaccorsi, A. 1992. On the relationship between firm size and export intensity. Journal of International Business Studies, 23: 605-635.

Colantone, I., Coucke, K., \& Sleuwaegen, L. 2008. Globalisation and firm exit: differences between small and large firms. Vlerick Leuven Gent Management School Working Paper Series.

Crick, D. 2002. The decision to discontinue exporting: SMEs in two UK trade sectors. Journal of Small Business Management, 40: 66-77.

Crick, D. 2003. The international entrepreneurial decision of UK SMEs to discontinue overseas activities: A research note reporting practices within the clothing industry eighteen months on. Journal of International Entrepreneurship, 4: 405-413.

Crick, D. 2004. UK SMEs' decision to discontinue exporting: An exploratory investigation into practices within the clothing industry. Journal of Business Venturing, 19: 561-587.

D’Angelo, A., Majocchi, A., Zucchella, A., \& Buck, T. 2013. Geographical pathways for SME internationalization: Insights from an Italian sample. International Marketing Review, 30: 80-105.

Dunning, J. H. 1980. Towards an eclectic theory of international production: Some empirical tests. Journal of International Business Studies, 11: 9-31.

Eaton, J., Eslava, M., Kugler, M., \& Tybout, J. 2008. Export dynamics in Colombia: Transactions level evidence. Borradores de Economia 004748, Banco de la República.
${ }^{6}$ Production functions are estimated separately for different two-digit ISIC sectors.

${ }^{7}$ This variable is constructed by using data from the OECD Structural Analysis Dataset (STAN).

${ }^{8} \mathrm{We}$ take logs to deal with nonlinearity in the probability of exporting over a firm's age.

${ }^{9}$ Note that this is quite independent of the IMR finding. One result (IMR) tells us that certain unobserved factors both discourage export exit and encourage re-entry: the other (length of time) tells us that, even after allowing for the link between export and re-entry determinants, the longer a firm is out of exporting the less likely it is to re-enter.

${ }^{10}$ The one exception is productivity (TFP), which has a consistently positive effect on the probability on reentry.

Eaton, J., Kortum, S., \& Kramarz, F. 2004. dissecting trade: firms, industries, and export destinations. American Economic Review, 94: 150-154.

Egger, P. H., \& Lassmann, A. 2015. The causal impact of common native language on international trade: Evidence from a spatial regression discontinuity design. Economic Journal, 125: 699-745.

Ganotakis, P., \& Love, J. H. 2012. Export propensity, export intensity and firm performance: The role of the entrepreneurial founding team. Journal of International Business Studies, 43: 693-718.

Görg, H., \& Spaliara, M.-E. 2014. Financial health, exports, and firm survival: Evidence from UK and French firms. Economica, 81: 419-444.

Greenaway, D., \& Kneller, R. 2007. Firm heterogeneity, exporting and foreign direct investment. Economic Journal, 117: F134-F161.

Hashai, N., \& Almor, T. 2004. Gradually internationalizing 'born global' firms: An oxymoron? International Business Review, 13: 465-483.

Ilmakunnas, P., \& Nurmi, S. 2010. Dynamics of export market entry and exit. Scandinavian Journal of Economics, 112: 101-126.

ISGEP. 2008. Understanding cross-country differences in exporter premia: Comparable evidence for 14 countries. Review of World Economics, 144: 596-635.

Johanson, J., \& Vahlne, J.-E. 1977. The internationalization process of the firm-A model of knowledge development and increasing foreign market commitments. Journal of International Business Studies, 8: 23-32.

Johanson, J., \& Vahlne, J.-E. 2006. Commitment and opportunity development in the internationalization process: A note on the Uppsala internationalization process model. Management International Review, 46: 165-178.

Johanson, J., \& Vahlne, J.-E. 2009. The Uppsala internationalization process model revisited: From liability of foreignness to liability of outsidership. Journal of International Business Studies, 40: 1411-1431.

Johanson, J., \& Wiedersheim, F. P. 1975. The internationalization of the firm: Four Swedish cases. Journal of Management Studies, 12: 305-323. 
Jones, M. V., \& Coviello, N. E. 2005. Internationalisation: Conceptualising an entrepreneurial process of behavior in time. Journal of International Business Studies, 36: 284-303.

Knight, G. A., \& Cavusgil, S. T. 2004. Innovation, organizational capabilities, and the born-global firm. Journal of International Business Studies, 35: 124-141.

Lages, L. F., Jap, S. D., \& Griffith, D. A. 2008. The role of past performance in export ventures: A short-term reactive approach. Journal of International Business Studies, 39: 304-325.

Levinsohn, J., \& Petrin, A. 2003. Estimating production functions using inputs to control for unobservables. Review of Economic Studies, 70: 317-341.

Lin, W.-T. 2014. How do managers decide on internationalization processes? The role of organizational slack and performance feedback. Journal of World Business, 49: 396-408.

Love, J. H., \& Ganotakis, P. 2013. Learning by exporting: Lessons from high-technology SMEs. International Business Review, 22: 1-17.

Love, J. H., \& Mansury, M. A. 2009. Exporting and productivity in business services: Evidence from the United States. International Business Review, 18: 630-642.

Love, J. H., Roper, S., \& Zhou, Y. 2016. Experience, age and exporting performance in UK SMEs. International Business Review, 25: 806-819.

Majocchi, A., Bacchiocchi, E., \& Mayrhofer, U. 2005. Firm size, business experience and export intensity in SMEs: A longitudinal approach to complex relationships. International Business Review, 14: 719-738.
Martins, P. S., \& Yang, Y. 2015. Globalised labour markets? International rent sharing across 47 countries. British Journal of Industrial Relations, 53: 664-691.

Melitz, M. J. 2003. The impact of trade on intra-industry reallocations and aggregate industry productivity. Econometrica, 71: 1695-1725.

Requena-Silvente, F. 2005. The decision to enter and exit foreign markets: Evidence from UK SMEs. Small Business Economics, 25: 237-253.

Salomon, R., \& Shaver, J. M. 2005. Learning by exporting: New insights from examining firm innovation. Journal of Economics and Management Strategy, 14: 431-460.

Sui, S., \& Baum, M. 2014. Internationalization strategy, firm resources and the survival of SMEs in the export market. Journal of International Business Studies, 45: 821-841.

Wagner, J. 2007. Exports and productivity: A survey of the evidence from firm-level data. The World Economy, 30: 60-82.

Wagner, J. 2008. Export entry, export exit and productivity in German manufacturing industries. International Journal of the Economics of Business, 15: 169-180.

Welch, C. L., \& Welch, L. S. 2009. Re-internationalisation: Exploration and conceptualisation. International Business Review, 18: 567-577.

Wennberg, K., \& Holmquist, C. 2008. Problemistic search and international entrepreneurship. European Management Journal, 26: $441-454$.

\section{APPENDIX: VARIABLE CORRELATION COEFFICIENTS AND SUMMARY STATISTICS}

See Tables A1 and A2.

Table A1 Correlation coefficients

\begin{tabular}{|c|c|c|c|c|c|c|c|c|c|c|c|c|c|c|}
\hline & (1) & (2) & (3) & (4) & (5) & (6) & (7) & (8) & (9) & (10) & (11) & (12) & (13) & (14) \\
\hline 1- $\Delta \mathrm{Dom}_{s}$ & 1 & & & & & & & & & & & & & \\
\hline 2- $\Delta$ For $_{s}$ & -0.055 & 1 & & & & & & & & & & & & \\
\hline 3- $\operatorname{age}_{i}$ & 0.004 & -0.009 & 1 & & & & & & & & & & & \\
\hline $4-K_{i}$ & -0.005 & 0.01 & 0.22 & 1 & & & & & & & & & & \\
\hline 5- emp $p_{i}$ & 0.051 & -0.025 & 0.215 & 0.254 & 1 & & & & & & & & & \\
\hline 6- TFP $\mathrm{i}_{\mathrm{i}}$ & -0.025 & -0.013 & 0.116 & 0.216 & 0.453 & 1 & & & & & & & & \\
\hline $7-\ln (s)$ & -0.144 & 0.309 & 0.221 & 0.212 & 0.223 & 0.165 & 1 & & & & & & & \\
\hline 8- $\Delta \mathrm{Dom}_{\mathrm{s}} \times \mathrm{K}_{\mathrm{i}}$ & 0.933 & -0.041 & 0.023 & 0.117 & 0.082 & 0.004 & -0.125 & 1 & & & & & & \\
\hline 9- $\Delta$ For $_{s} \times \mathrm{K}_{\mathrm{i}}$ & -0.04 & 0.926 & 0.037 & 0.152 & 0.019 & 0.019 & 0.343 & -0.013 & 1 & & & & & \\
\hline $10-\Delta$ Dom $_{s} \times, \ln (s)$ & 0.917 & -0.036 & 0.026 & 0.028 & 0.066 & 0.003 & 0.028 & 0.888 & -0.012 & 1 & & & & \\
\hline 11- $\Delta$ Fort $s, \times \ln (s)$ & -0.087 & 0.849 & 0.072 & 0.076 & 0.046 & 0.045 & 0.46 & -0.068 & 0.843 & -0.024 & 1 & & & \\
\hline 12- $\Delta \operatorname{Dom}_{\mathrm{s}} \times \mathrm{emp}_{\mathrm{i}}$ & 0.871 & -0.038 & 0.032 & 0.037 & 0.219 & 0.046 & -0.118 & 0.856 & -0.022 & 0.828 & -0.067 & 1 & & \\
\hline 13- $\Delta$ For $_{\mathrm{s}} \times \mathrm{emp}_{\mathrm{i}}$ & -0.019 & 0.853 & 0.045 & 0.063 & 0.181 & 0.076 & 0.333 & -0.003 & 0.845 & 0.001 & 0.811 & 0.027 & 1 & \\
\hline 14- $\Delta$ Dom $\times$ TFP $_{i}$ & 0.616 & -0.015 & 0.03 & 0.061 & 0.156 & 0.238 & -0.043 & 0.634 & 0.008 & 0.618 & -0.013 & 0.691 & 0.032 & 1 \\
\hline $15-\Delta$ For $_{s} \times$ TFP $_{i}$ & -0.014 & 0.601 & 0.036 & 0.079 & 0.141 & 0.323 & 0.241 & 0.006 & 0.628 & 0.023 & 0.621 & 0.015 & 0.694 & 0.106 \\
\hline
\end{tabular}


Table A2 Summary statistics

\begin{tabular}{|c|c|c|c|c|}
\hline & Mean & SD & Min. & Max \\
\hline \multicolumn{5}{|c|}{ Sample exit model } \\
\hline$\Delta$ Dom & 0.025 & 0.061 & -2.597 & 2.702 \\
\hline$\Delta$ For & 0.025 & 0.083 & -3.255 & 3.393 \\
\hline$K$ & 3.072 & 1.164 & -5.149 & 12.674 \\
\hline TFP & 0.446 & 0.999 & -18.858 & 8.211 \\
\hline empl & 1.68 & 1.386 & 0 & 11.341 \\
\hline age & 2.487 & 1.068 & 0 & 4.682 \\
\hline $\ln (s)$ & 1.279 & 0.759 & 0 & 2.397 \\
\hline \multicolumn{5}{|c|}{ Sample re-entry model } \\
\hline$\Delta$ Dom & 0.017 & 0.061 & -2.374 & 2.5 \\
\hline$\Delta$ For & 0.075 & 0.09 & -0.37 & 0.418 \\
\hline$K$ & 3.22 & 1.104 & -5.149 & 10.339 \\
\hline TFP & 0.517 & 1.043 & -15.785 & 8.125 \\
\hline empl & 2.194 & 1.284 & 0 & 11.341 \\
\hline age & 2.984 & 0.762 & 1.098612 & 4.682 \\
\hline $\ln (s)$ & 0.935 & 0.663 & 0 & 2.197 \\
\hline
\end{tabular}

\section{ABOUT THE AUTHORS}

Michele Bernini holds a Ph.D in International Economics and has conducted research at NIESR and the University of Sheffield. He is an applied micro-econometrician with interests in international trade, policy evaluation and firm-level analysis. His quantitative research mainly explores the interplay between different dimensions of firm heterogeneity and export performance.

Jun Du is Professor of Economics at Aston Business School and Enterprise Research Centre, UK. Her main research interest is to understand the driving forces and impediments of productivity enhancement and economic growth, from multi-level dimensions of individuals, firms, industries, regions, governments, and their interplays, in both mature and emerging economies.

James $\mathbf{H}$ Love is Professor of International Business and Innovation at Warwick Business School and
Enterprise Research Centre, UK. His research interests include the relationship between innovation, exporting and firm performance, the role of the MNE as a source of intra-firm and international knowledge transfer, and the dynamics of open innovation.

Open Access This article is distributed under the terms of the Creative Commons Attribution 4.0 International License (http://creativecommons. org/licenses/by/4.0/), which permits use, duplication, adaptation, distribution and reproduction in any medium or format, as long as you give appropriate credit to the original author(s) and the source, provide a link to the Creative Commons license and indicate if changes were made. 